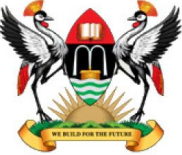

East African School of

Higher Education Studies \& Development
Makerere Journal of Higher Education

ISSN: 1816-6822; 5 (1) (2013) 23 ï 33

DOI: http://dx.doi.org/10.4314/majohe.v5i1.2

(C) The Author(s) 2013

Reprints \& permission: EASHESD

http://ajol.info/majohe

\title{
ICT and Decision Making in Universities in North-Central Geo-Political Zone, Nigeria
}

\author{
A. T. Alabi ${ }^{1}$, O. P. Akinnubi ${ }^{2}$ \\ ${ }^{1}$ Department of Educational Management, University of Ilorin [Corresponding author: \\ alabiafusat@yahoo.com], ${ }^{2}$ Department of Educational Management, Al-Hikmah University
}

\begin{abstract}
This study investigated the use of ICT for decision-making in NorthCentral Nigerian universities. It adopted a correlation design, in which four out of the seven federal universities were chosen, using stratified random sampling techniques. A total of 240 participants responded to an instrument entitled: ICT and Decision-making Questionnaire. The data collected were analysed using means, frequency counts, percentage, rank ordering and chi-square. Findings revealed that printing ICT equipment were adequate while electronic equipment were fairly adequate in the universities. In addition, ICT has been effectively utilized for decisions on studentsô registration procedures and budgeting. Inadequate funding and ICT equipment were ranked topmost among problems of ICT in the universities. Based on the findings, recommendations towards more effective deployment of ICTs in the universities operations are made.
\end{abstract}

Keywords: Decision making; Nigerian universities; ICT.

\section{$1 \quad$ Introduction}

There are increasing societal demands on Nigerian modern educational institutions for good results in terms of the functionality of the type of education given. University education in particular is looked upon for meeting the manpower needs of the country. Thus, universities are complex organisations with multiple goals which are accomplished through their major roles of teaching, research and community service (FRN, 2004).

The more complex an organisation $\hat{Q}$ structure is, the greater the need for coordination within and between sections and departments. However, central to the needed coordination is information. This view is buttressed by Ekwere (1990) that the information needed for effective decision making in universities cannot be provided from peopleâs often deficient memories. To be effective 
therefore, a university needs a system that creates knowledge, stores the knowledge so created and established to ensure continuity of thought, reason and adaptive academic pursuit; and recall at will and disseminate the stored knowledge or information for use in taking decisions which are in the interest of the society at large (Adedipe, 1995).

In the university system, information is supplied to people both within and outside the system. Information is made available on:

1. Degree offered;

2. Courses/departments/faculties available and their requirements, to parents and prospective students;

3. Consultancy services to be rendered to people within and outside the university campuses;

4. Plans and performance standard to the government through the National Universities Commission (NUC).

For the Nigerian university system to meet the manpower needs of the country, relevant and timely information is needed in some areas on which to base decisions on its activities. Such areas include:

1. Demographic data on potential secondary education output;

2. Student population, composition, socio-economic background, male/female ratio, assessment of academic progress;

3. Staff categories, salaries, workloads, evaluation, updating of knowledge;

4. Accounting data, both for planning and operational purposes;

5. Data for evaluation of curricula and teaching methods;

6. Utilization and relative utility value of services such as material resources and student welfare services.

\subsection{Theoretical Background}

ICT is part of today $\hat{Q}$ reality and should be accessible to all categories of people in educational institutions at all levels. Information and Communication Technologies are defined as a set of technological tools and resources used to communicate, and to create, disseminate, store, and manage information (UNDP, 2000). Such technologies include radio, television, video, DVD, telephone, satellite systems, computers and network hardware and software as well as the equipment and services associated with these technologies such as video-conferencing and electronic mail (UNESCO, 2002).

Information is knowledge, communicated by others or obtained by study and investigation, upon which intelligent action is based. The function of information is thus to reduce the amount or range of uncertainty under which decisions are made. In the opinion of Oyebode (1997), effective information 
management processing, flow and utilization are vital to the survival of any organization. This is more so in complex organizations like the universities. For organizational members to achieve the desired interdependence towards goal attainment there must be effective communication channels.

Decision making is an integral part of the management of any organisation. As such, the quality of managersô decisions is the yard stick .of their effectiveness and of their value to the organisation. Ogunsaju (1990) posited that solutions to administrative problems can only be provided through the process of decision-making. A decision is a choice made from, at least two alternatives, making the choice only part of the decision-making process. According to Swann (1993), decision-making is an interactive process involving the recognition of an opportunity or a problem, obtaining data, understanding the information content, seeking alternatives, evaluating them, making choices and implementation.

Decision-making process is influenced by many factors, including information on the organisation $\hat{Q}$ internal and external environments, and managerôs ability and motivation (Libby and Luft, 1993). In the same vein, Cowan (1991) concluded that decision-making starts with the initial recognition of a problem, or an issue that is worthwhile making decision about, through the collection of data, the identification of the real situation, the development of alternatives, and the evaluation to the final choice that is implemented and controlled. Thus, as elucidated by Donnelly, Gibson and Ivancevich (1995), the sequence of events that lead to effective decision include problem identification, developing and evaluating alternatives, choosing the best alternative, implementing the decision and monitoring the decision using the built-in information (control and evaluation).

Within the Nigerian university, decision-making procedures start with information emanating from the different departments and units. The information (both on academic and administrative matters) is passed to the administration for necessary action. The universities make use of committee system in taking decisions. It is however, crucial that deliberations, recommendations and ultimate decisions should be based on accurate, comprehensive and up-to-date information, if they are to be effective.

Therefore, for effective decision to evolve in the university system, receiving information from, and supplying to people within the system, is a necessity (Alabi, 1999). The information so communicated must be accurate and up-todate to cope with uncertainty (Stahl, 1995). There is therefore the need for effective ICT to ensure effective decision making. 


\subsection{Rationale for the Study}

Information has become the sixth major corporate resource, assuming a value just as any of the 5Mố ï Money, Material, Machines and facilities, Men (people) and Management (Thierauf, 1987). Hence, information must be planned, preserved, protected, controlled and utilized maximally, as these other resources. So, considering the globalized nature of the society brought about by information explosion, there is the need to ensure that Nigerian universities, as the citadels of learning, employ effective ICT. This would enable the universities to base their major decisions on relevant, appropriate, timely information for global competitiveness of their process and outputs.

\subsection{Statement of the Problem}

In view of the complex nature of Nigerian universities, availability and effective use of ICT are imperative. Effective generation and use of information is necessary for the universities to develop good plans, policies, programmes and activities towards the achievement of the goals of university education in the country. The concern of this study is on the existing ICT and the extent to which information generated there from is put to use in deciding on the different aspects of university administration.

\section{$1.4 \quad$ Research Questions}

1. How adequately equipped are the Nigerian universities in the North Central zone in terms of ICT equipment?

2. Are administrative decisions on programmes and activities based on information from ICT?

3. What problems do Nigerian universities encounter in generating information and utilizing the information generated by the ICT?

\subsection{Research Hypothesis}

There is no significant difference among students, lecturers and senior administrative staff in the use of ICT in decision making on student personnel services.

\section{$2 \quad$ Methodology}

The study was designed to examine the use of ICT by Nigerian universities for decision making on studentsôpersonnel services and budgeting. Using stratified random sampling technique, four federal universities were chosen out of the 
seven in the North Central Geo-political zone. These were universities of Ilorin and Abuja, Federal university of Agriculture Makurdi and Federal university of Technology, Minna.

A total of 240 participants comprising 100 lecturers, 60 senior administrators and 80 student leaders responded to questionnaires entitled ñICT and Decisionmaking Questionnaireò (ICTDQ) I, II and III for students, lecturers and senior administrative officers, respectively. The instruments consisted of items to indicate available ICT equipment and the use of ICT for decision-making on student personnel services and budgeting. Available ICT equipment investigated included Electronic (Computers, Telephones, Telex, Fax, E-mail and Communications Satellites and Radio) as well as Printing such as Postal Services, Administrative Files and Publications (Handbooks, Bulletins, Brochures etc). There were items to determine the use of information generated from ICT for Budgeting, Student Services such as Programme Application and Courses Registration, Examination Conduct and Results, and Hostel Accommodations. The reliability of the questionnaires was ascertained through test re-test method within a three-week interval, with reliability coefficients of $0.83,0.89$ and 0.81 for ICTDQ I, II and III, respectively.

Descriptive statistical methods of frequency counts, mean, percentage and rank ordering were employed to answer the research questions raised in the study, while chi-square statistical method was used to test the hypothesis at .05 significance level. A NORM was set at $50 \%$ for adequacy of ICT equipment. The results of the analysis are presented on the basis of research questions raised and the hypothesis formulated as follows:

\section{$3 \quad$ Findings}

Research Question 1: How adequately equipped are universities in the North Central Geo-political Zone, Nigeria?

Table 1: Adequacy of MIS Equipment in the Universities $(\mathrm{N}=\mathbf{2 4 0})$

\begin{tabular}{llccccc}
\hline Variable & & \multicolumn{3}{c}{ Adequacy } & & \\
& & Very Adequate & & Fairy Adequate & & Not Available \\
& $\mathrm{f}$ & $\%$ & $\mathrm{f}$ & $\%$ & $\mathrm{f}$ & $\%$ \\
Electronic & 76 & 31.6 & 144 & 60.2 & 20 & 8.3 \\
Printing & 167 & 69.5 & 73 & 30.5 & 0 & 0 \\
Combined & 205 & 85.3 & 35 & 14.7 & 0 & 0 \\
\hline
\end{tabular}

Results from Table 1 indicate that MIS electronic equipment such as computers, telephones, intercoms, Telex, fax, e-mail and communications satellites were adjusted by most respondents as fairly adequate 144 (60.2\%). Postal services, publication and administrative files were adjudged very 
adequate $167(69.50 \%)$ while combination of both electronic and printing equipment were rated as very adequate 205 (85.3\%).

Research Question 2: Are administrative decisions on student personnel services and budgeting based on information from ICT?

Table 2: Use of ICT in Decision-making on Students' Personnel Services and Budgeting

\begin{tabular}{|c|c|c|c|c|c|c|c|}
\hline \multirow{2}{*}{$\begin{array}{l}\text { Variable } \\
\text { Student Personal } \\
\text { Services }\end{array}$} & \multicolumn{2}{|c|}{ Students } & \multicolumn{2}{|c|}{ Lecturers } & \multicolumn{2}{|c|}{$\begin{array}{l}\text { Senior } \\
\text { Administrators }\end{array}$} & \multirow{2}{*}{ Remarks } \\
\hline & Mean & $\%$ & Mean & $\%$ & Mean & $\%$ & \\
\hline $\begin{array}{l}\text { a) Registration } \\
\text { Procedures }\end{array}$ & 4.156 & 51.95 & 4.567 & 57.09 & 4.781 & 59.76 & Effective \\
\hline $\begin{array}{l}\text { b) Conduct of } \\
\text { Examination }\end{array}$ & 3.400 & 37.77 & 4.00 & 40.00 & 4.47 & 48.06 & Ineffective \\
\hline $\begin{array}{l}\text { c) Release of } \\
\text { Examination Results }\end{array}$ & 3.10 & 34.67 & 3.49 & 43.82 & 3.575 & 48.81 & Ineffective \\
\hline $\begin{array}{l}\text { d) Allocation of Hostel } \\
\text { Accommodation }\end{array}$ & 3.906 & 39.72 & 3.35 & 43.76 & 3.944 & 43.82 & Ineffective \\
\hline Budgeting & NA & 'NA & NA & NA & 3.033 & 60.66 & Effective \\
\hline
\end{tabular}

Research Question 3: What problems do Nigerian universities encounter in generating information and utilizing the information generated by the ICT?

Table 3: Rank order of the ten most prominent problems of ICT in Nigerian universities

\begin{tabular}{lcl}
\hline Problem Statement & Mean & Rank \\
\hline Poor support from management & 3.133 & 5 \\
Poor support from university staff & 3.190 & 4 \\
Inadequate funding of ICT & 3.762 & 1 \\
Inadequate ICT equipment in the university & 3.620 & 2 \\
Inadequate qualified personnel for ICT Operation & 3.010 & 6 \\
Poor communication network & 3.267 & 3 \\
Inadequate security for stored information & 2.690 & 9 \\
Lack of customised software for the use of the university & 2.860 & 8 \\
Inadequate literacy in computer by key university officers & 2.910 & 7 \\
Ignorance of ICT knowledge by university personnel & 1.890 & 10 \\
\hline
\end{tabular}

Research Hypothesis: There is no significant difference among students, lecturers and senior administrative staff in the use of ICT in decision making on student personnel services. 
Table 4: Use of ICT on student personnel services among students, lecturers and senior administrative staff

\begin{tabular}{|c|c|c|c|c|c|c|c|c|}
\hline Items & Lecturers & $\mathrm{SA}^{*}$ & Students & Total & df & $\begin{array}{l}\mathrm{X}^{2} \\
\text { Value }\end{array}$ & Sig. & Remark \\
\hline $\begin{array}{l}\text { Registration } \\
\text { Procedure }\end{array}$ & 28 & 18 & 32 & 78 & & & & \\
\hline $\begin{array}{l}\text { Conduct of } \\
\text { Examination }\end{array}$ & 18 & 15 & 21 & 54 & & & & \\
\hline $\begin{array}{l}\text { Release of } \\
\text { Examination }\end{array}$ & 35 & 14 & 17 & 66 & 6 & 9.183 & 0.167 & $\begin{array}{l}\text { Not } \\
\text { Significant }\end{array}$ \\
\hline $\begin{array}{l}\text { Allocation of } \\
\text { Hostel } \\
\text { Accommodation }\end{array}$ & 19 & 13 & 10 & 42 & & & & \\
\hline Total & 100 & 60 & 80 & 240 & & & & \\
\hline
\end{tabular}

Table 4 shows that there was no significant difference $\left(X^{2}=9.183, d f=6\right.$, p>.05) among students, lecturers and senior administrative staff in the use of ICT in decision making on student personnel services.

\section{Discussion}

Table 1 shows that electronic ICT equipment are adjudged fairly adequate by $60.2 \%$ of the participants in the universities in North Central Nigeria, while printing equipment were adequately available (69.5\%). Combination of both electronic and printing equipment gave a very adequate availability (85.3\%). This general inadequacy of ICT electronic equipment does not augur well for effective decision-making based on accurate and timely information (Alabi, 2000). This equipment is compulsory for any successful ICT-driven programme (Trotter, 2001).

Table 2 reveals the use of ICT-based information for decisions on students q́ersonnel services and budgeting in the universities. Only registration procedures and budgeting had relative effectiveness in the use of ICT (average percentages of 56.27 and 60.66, respectively). Information on examination process and results as well as allocation of accommodation to students has not been effectively based on electronic ICT. It is noteworthy that applications into Nigerian universities are done online. Registration of courses in most of them is also online. However, internal examinations are mainly through Pen-and-Paper Testing (PPT) method. With the exception of university of Ilorin that employs Computer Based Testing (CBT) for, on the average, 88 courses per session (Alabi, Issa \& Oyekunle, 2012). In addition, allocation of hostel accommodation to students at the University is done online with some degree 
of objectivity and fairness. Admission and registration procedures usually done online, have brought a lot of improvement to the admission into the Nigerian universities (Blurton, 2002).

Table 3 gives the rank-order of the problems confronting ICT operations in the universities. These problems ranged from inadequate funding and ICT equipment, poor communication network to inadequate human resources capacity to exploit the technology. This finding corroborated The National Governors Association (2002) that listed as constraints to ICT operations in education, lack of: ICT infrastructure, affordable connectivity with sufficient bandwidth, and a reliable supply of electricity. The three most important goals of university education ranked by academic staff were teaching postgraduate and research (Oduwaiye, 1998). Hence, students, according to Baldrige (1991), are at the centre of all the activities and programme of the university. In practical terms, the activities include admission/registration of students, examination administration and certification. However, as important as student certification is, prompt grading and timely release of examination results, which precede certification, is rated as inadequate. The poor support from management could emanate from the perspective of funding and policies, while the poor support from staff could be due to inadequate computer education. Lack of customised software and inadequate security for stored information in computer ranked $8^{\text {th }}$ and $9^{\text {th }}$, respectively.

Table 4 implies that there was no significant difference among students, lecturers and senior administrative staff in the use of ICT in decision-making on student personnel services. It can be deduced from the results of the analysis that lecturers, senior administrators and students are exposed to the use of ICT in student personnel services. There is no gainsaying the fact that ICT has become a natural part of manô daily life; hence, its effective use in the university system is becoming a necessity (Galbreath, 2000). Sule and Akinnubi (2012) submitted that lecturersô roles and responsibilities in their work place can be enhanced through effective use of ICT. Gbadamosi (2006) noted that ICT is a factor that can promote quality instruction and administration in higher education. Also, communication is a fundamental act of the education process. Therefore, to enhance effective decision-making in Nigerian universities, adequate attention must be given to the use of ICT.

\section{Conclusion}

ICT is part of todayôs reality and should be accessible to all categories of people in educational institutions at all levels. However, in spite of the global awareness for ICT-driven sectors of the economy, especially the education 
sector, much is still expected of the university system in the area of procurement and use of ICT equipment for the crucial decision areas of university administration. Such important areas involve student services and overall budgeting of the university system.

Universities in North Central Geo-political zone of Nigeria have fairly adequate electronic ICT equipment. Probably due to this, there is ineffective use of ICT for decisions on student personnel services of examination conduct and release of results as well as accommodation. However, decisions on admission/registration procedures and budgeting are based on ICT.

\section{Recommendations}

The use of ICT, specifically CBT is recommended for examination of courses to ensure prompt and timely release of studentsô results. These results are needed by students (and their parents too) to know their performances and where to proceed, based on these performances.

Software is the medium of communication with the computer, using the ómachine languageô Hence, for utilizing the full capacity of the computers in taking care of specific areas of operation of each university, there is the need for development of customized software.

Any form of ICT development is capital intensive. As necessary inputs to effective management systems in the universities, computers and their accessories as well as other related technologies such as telephone system, telex, fax and e-mail services need to be provided, to ensure appropriate and adequate dissemination of necessary information within and outside the university system.

In each university, there is the need for a common database of objective and systematic information on which to base decision on studentsô services. For instance, allocation of halls of residence to students should be online for objectivity and on faculty basis, so as to bring about useful interaction and exchange of ideas and knowledge among the students of various disciplines.

Though ICT is effectively employed for budgeting in the universities, budgetary procedures can still be improved. To encourage more allocation from governments, it is recommended that uniform accounting system which seeks to organise and harmonise methodically the financial records of all the universities should be introduced using appropriate software.

As it is the practice at the University of Ilorin, CBT should be employed for assessing students in the university-wide and faculty courses. With time, CBT should be extended to all courses. 
It is also recommended that every university should emulate the University of Ilorin in establishing an FM Radio Station. The University of Ilorin 89.3 FM station is used in disseminating crucial information on administrative and academic activities to the University community. Lectures and explanations on general and specific university courses such as English Language and General Studies are delivered on the Radio. The Radio station delivers educative, informative and entertaining programmes to the entire university community and its environs.

As any form of ICT development is capital intensive, other Nigerian universities should learn from the University of Ilorin by involving private organisations as partners in progress to finance CBT.

For a successful ICT-driven decision making process, there must be a properly focused and consistent ICT policy orientation in each university to support building of pervasive ICT infrastructure, focused capacity building in human resources and favourably enabling legal, regulatory and policy environments. Towards this end, staff and students of the universities need adequate competencies in computer skills through adequate computer skill acquisition training programmes.

\section{References}

Adedipe, N.O. (1995). University management constraints and stresses: A personal experience. Text of a keynote address at the 1995 MIS national seminar organised by NUC.

Alabi, A.T. (1999). Effective utilization of management information system for decision-making in Nigerian Universities. Unpublished $\mathrm{PhD}$ thesis, University of Ilorin.

Alabi, A.T. (2000). Management information system equipment utilization in Federal and State universities in Nigeria. Ilorin Journal of Education, 20, 105-112.

Alabi, A.T., Issa A.O. \& Oyekunle, R.A. (2012). The Use of Computer Based Testing Method for the Conduct of Examination at the University of Ilorin. International Journal of Learning and Development, 2, (3), 69-80.

Blurton, C. (2002). New directions of ICT use in education. http://www.unesco.org/education/educationprog/lwf/al/edict.pdf

Cowan, D.A. (1991). Developing a process model of problem recognition. Academy of Management Review, 4, 63-83.

Donnelly, J.H., Gibson, J.L. \& Ivancevich, J.M. (1995). Fundamental of management $\left(9^{\text {th }}\right.$ ed.). Chicago: Irwin. 
Ekwere, C.E. (1990). Evaluation of the management information systems in universities: The case of University of Cross River State, Uyo. Unpublished Ph.D. thesis, University of Ibadan

Gbadamosi, L. (2006). Challenges of e-teaching profession and ways forward: An educational plannerôs view. Paper presented at ICT workshop organized by Teacher Registration Council of Nigeria (TRCN). Adeniran Ogunsanya College of Education, Ijanikin, Lagos, $2^{\text {nd }}$ i $8^{\text {th }}$ July

Libby, R., \& Luft, J. (1993). Types of organisational decision processes. Administrative Science Quarterly, 192-209.

National Governors Association (2002). Using electronic assessment to measure student performance. Education Policy Studies Division: National Governors Association.

Ogunsaju, S. (1990). A guide to school effectiveness in Nigeria. Ibadan: Laville. Oyebode, M.O. (1997). Information flow and employees' productivity: A case study of International Breweries limited, Ilesha. M.Ed. thesis, University of Ibadan, Ibadan.

Stahl, M.J. (1995). Management: total quality in a global environment. Cambridge, U.S.A.: Blackwell.

Sule, A. O. \& Akinnubi, O. P. (2012). Computer literary and lecturers' job performance in Colleges of Education, Kwara State, Nigeria. International Edited conference proceedings, South-Africa: TRCN Publication, 165-169.

Swann, D. (1993). Decisions, decision: First get the facts. Management Review, 58-61.

Thierauf, R.J. (1987). Effective management information system ( $2^{\text {nd }}$ ed.). Ohio: Merril.

Trotter, A. (2001). Testing computerized exam. Education week, 20, (37), 3035. http://www.edweek.org/ew/ewstory.cmf?slug=37online.h20. 
